
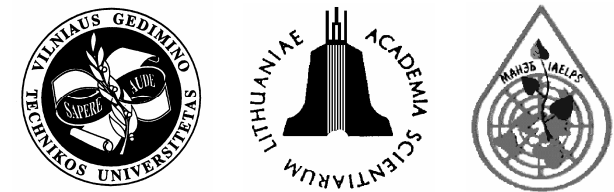

\title{
SOIL WATER MOVEMENT MODELLING IN HAPLLICC LUVISOLS (HMm) AND ALBI HAPLLIC LUVISOLS (HMI) UNDER SLOVAK CLIMATIC CONDITIONS
}

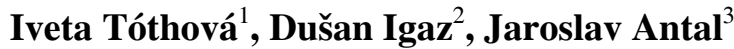 \\ Dept of Biometeorology and Hydrology, Slovak Agricultural University in Nitra, Hospodárska 7, 94976 Nitra, \\ Slovak Republic.E-mail: ${ }^{1}$ Iveta.Tothova@uniag.sk; ${ }^{2}$ Dusan.Igaz@uniag.sk; ${ }^{3}$ Jaroslav.Antal@uniag.sk
}

Submitted 8 Mar 2006; accepted 25 Mar 2006

\begin{abstract}
The aim of the research paper is simulation by the Global Model on the basis of investigation of Slovak Agricultural University (SAU) on two localities (Kolínany and Malanta). The soil moisture was measured by a time domain transmissometry instrument and compared with simulated outputs of the Global Model on Kolíňany locality. Measurement of the soil moisture using the gravimetric method was applied on Malanta locality. Sugar beet was grown in Kolínany and, on the other hand, there was no plant on Malanta soil during the experiment. The experiment took three years (2002-2004). Measured and simulated courses of water content were consequently tested by correlation analysis in MS Excel. Result differences between simulated and measured values should reach according to $15 \%$ difference at least $80 \%$ of equality. Correlation between measured and simulated values had a high significance on Kolínany locality (in the range of $0,62-0,90$ ) Equality between measured and simulated values was from $33 \%$ to $75 \%$ according to difference of $15 \%$.
\end{abstract}

Keywords: soil, water content, moisture, mathematical Global Model, correlation, gravimetric method.

\section{Introduction}

Soil water content is expressed on a gravimetric or volumetric basis. Gravimetric water content $(w)$ is the mass of water per mass of dry soil. It is measured by weighing a soil sample $\left(m_{t}\right)$, drying the sample to remove the water, then weighing the dried soil $\left(m_{s}\right)$.

$$
w=\frac{m_{w}}{m_{s}}=\frac{m_{t}-m_{s}}{m_{s}} .
$$

Volumetric water content $(\theta)$ is the volume $\left(V_{w}\right)$ of liquid water per volume of soil $\left(V_{t}\right)$.

$$
\theta=\frac{V_{w}}{V_{t}}
$$

Knowledge of the soil water content is important, for example, in budgeting water, planning drainage lines or irrigation. Although water often moves from regions of a higher water content to regions of a lower water content, it is the difference in soil water potentials, rather than water which hold different water amounts at the same potential energy status, would not experience a flow of water between regions [1].

Modeling of soil water movement under different crops was solved on the territory of Danubian lowland in the frame of some impacts studies [2-5]. These studies were focussed on yield - climate interactions, first of all the effect of environmental elements. Soil water content was evaluated only on level "by product", and so next experimental studies are needed for precise parametrization of the models. Precise parametrization of the model can help to take effective measures to reduce negative effects of environmental elements.

The numerical modeling is used for changes and regulation of soil water regime. This paper presents successful theoretical knowledge of hydrological model Global on the concrete example of climatic conditions in region Nitra.

The aim of this research paper is to compare simulated and monitored values of volumetric soil moisture on two localities of Kolínany and Malanta during growing season in 2002-2004.

\section{Investigation object and methodology}

Study areas

Kolíñany and Malanta is a part of Nitra region. Nitra is situated on the south-west of Slovakia. Altitude varies from 180 to 310 above the sea level. Monitored fields are situated 200 meters above the sea level. The following Tables 1-3 present evaluation of months according to rain reference climate period (RCP) 1951-80 in Nitra for years 2002-2004.

The groundwater level is 10 meters under the soil surface, and it did not affect the root zone. Nitra belongs to warm region, dry subregion, with mostly soft-winter climatic zone.

\section{Soil parameters}

Disturbed soil samples and small soil cores $\left(100 \mathrm{~cm}^{3}\right)$ were taken from the site of experimental surface. Organic carbon, porosity, bulk density and particle 
density were determined using standard procedures of soil physics. Saturated hydraulic conductivity Ks was estimated by in situ measurements using the constant hydraulic gradient. Retention curves of the soil sample, it means relationship between soil moisture and negative pressure head [6], were measured in laboratory with a pressure extractor.

The soil type is classified as sandy-loam Hapllic Luvisols (HMm) in Kolíňany [7]. The soil type is loamy clay classified like Albi Hapllic Luvisols (HMl) in Malanta [8].

The following Table 4 presents hydrophysical characteristics of soil profile, where $\theta_{s}$ is volumetric water content saturated, $\theta_{F C}$ is field water capacity, $\theta_{r}$ is volumetric water content residual, $K_{s}$ is saturated hydraulic conductivity and $\alpha, n$ is parameters of analytical equation retention curves by van Genuchten.

\section{Plants in the soil}

Sugar beet was integrated into crop rotation in the following race: common sunflower, corn, barley, sugar beet in Kolíňany. The soil was without plants in the study area of Malanta.

Table 1. Evaluation of months according to rain reference climate period (RCP) 1951-80 in Nitra for 2002

\begin{tabular}{l|c|c|c|c}
\hline \multicolumn{1}{c|}{ Month } & $\mathrm{P}(\mathrm{mm})$ & $\begin{array}{c}\mathrm{RCP} \\
1951-80\end{array}$ & $\begin{array}{c}\text { \%n from } \\
\mathrm{RCP}\end{array}$ & characteristic \\
\hline January & 11,9 & 31 & 38,4 & very dry \\
\hline February & 35,7 & 32 & 111,6 & normal \\
\hline March & 28,7 & 33 & 87 & normal \\
\hline April & 44,5 & 43 & 103,5 & normal \\
\hline May & 62,3 & 55 & 113,3 & normal \\
\hline June & 68,5 & 70 & 97,9 & normal \\
\hline July & 50,9 & 64 & 79,5 & normal \\
\hline August & 90 & 58 & 155,2 & very wet \\
\hline September & 62,1 & 37 & 167,8 & very wet \\
\hline October & 78,2 & 41 & 190,7 & very wet \\
\hline November & 42,0 & 54 & 77,8 & normal \\
\hline December & 37,7 & 43 & 87,7 & normal \\
\hline
\end{tabular}

Table 2. Evaluation of months according to rain reference climate period (RCP) 1951-80 in Nitra for 2003

\begin{tabular}{l|c|c|c|c}
\hline \multicolumn{1}{c|}{ Month } & $\mathrm{P}(\mathrm{mm})$ & $\begin{array}{c}\mathrm{RCP} \\
1951-80\end{array}$ & $\begin{array}{c}\text { \%n from } \\
\mathrm{RCP}\end{array}$ & characteristic \\
\hline January & 33 & 31 & 106 & normal \\
\hline February & 1 & 32 & 2 & extremely dry \\
\hline March & 2 & 33 & 7 & extremely dry \\
\hline April & 27 & 43 & 63 & dry \\
\hline May & 45 & 55 & 81 & normal \\
\hline June & 7 & 70 & 9 & extremely dry \\
\hline July & 92 & 64 & 144 & wet \\
\hline August & 24 & 58 & 41 & very dry \\
\hline September & 16 & 37 & 42 & very dry \\
\hline October & 66 & 41 & 161 & very wet \\
\hline November & 33 & 54 & 61 & dry \\
\hline December & 24 & 43 & 56 & dry \\
\hline
\end{tabular}

Table 3. Evaluation of months according to rain reference climate period (RCP) 1951-80 in Nitra for 2004

\begin{tabular}{l|c|c|c|c}
\hline \multicolumn{1}{c|}{ Month } & $\mathrm{P}(\mathrm{mm})$ & $\begin{array}{c}\text { RCP } \\
1951-80\end{array}$ & $\begin{array}{c}\text { \%n from } \\
\text { RCP }\end{array}$ & characteristic \\
\hline January & 55,9 & 31 & 180 & very wet \\
\hline February & 31,1 & 32 & 97,2 & normal \\
\hline March & 52,8 & 33 & 160 & very wet \\
\hline April & 36,3 & 43 & 84,42 & normal \\
\hline May & 36,9 & 55 & 67,1 & dry \\
\hline June & 93,8 & 70 & 134 & wet \\
\hline July & 33,8 & 64 & 52,81 & dry \\
\hline August & 19,4 & 58 & 33,44 & very dry \\
\hline September & 36,7 & 37 & 99,19 & normal \\
\hline October & 45,3 & 41 & 110,5 & normal \\
\hline November & 45,7 & 54 & 84,6 & normal \\
\hline December & 26,8 & 43 & 62,3 & dry \\
\hline
\end{tabular}

Table 4. Hydrophysical characteristics of soil profile

\begin{tabular}{c|c|c|c|c|c|c}
\hline & $\begin{array}{c}\theta_{s} \\
(\% \\
\text { vol })\end{array}$ & $\begin{array}{c}\theta_{F C} \\
(\% \\
\text { vol })\end{array}$ & $\begin{array}{c}\theta_{r} \\
(\% \mathrm{vol})\end{array}$ & $\begin{array}{c}K_{s} \\
\left(\mathrm{~cm}^{1} \mathrm{~d}^{1}\right)\end{array}$ & $\alpha$ & $n$ \\
\hline Kolíňany & 38,61 & 33,02 & 7,72 & 7 & 0,0019 & 1,5709 \\
\hline Malanta & 47,00 & 35,00 & 2,80 & 9,5 & 0,0011 & 1,6892 \\
\hline
\end{tabular}

\section{Measured soil moisture}

Experiment on the soil profile lasted since May till September (growing season) (2002-2004). The soil moisture was measured by a sensor Virrib. This sensor is based on the principle of propagation of electromagnetic waves through the medium. The body of the sensor is mechanically fixed with the embedding material which also prevents water from penetrating to the electronic part. The diameter of the outer ring is $280 \mathrm{~mm}$; its measurement capacity is 15-20 liters of soil. The output data are measured by means of a current loop, the intensity of the output current being directly proportional to the measured volume of moisture. Virrib can measure a layer of soil that is 120 $\mathrm{mm}$ thick when the sensor is placed in a horizontal position; a layer $300 \mathrm{~mm}$ thick can be measured when the sensor is in a vertical position. Of course, the sensor cannot measure the humidity conditions above and below this layer. However, by using two sensors located above each other, the technician can obtain information on moisture conditions to a greater depth in the root zone. In cases involving a crop with a shallow root system, the second sensor may be situated deeper in the soil to determine water soaking [9].

Time domain transmissometry set to measure volumetric water content was placed at the same horizontal depth below soil surface to $0,25 \mathrm{~m}$ in Kolíñany.

The gravimetric method was used to measure the gravimetric water content on Malanta locality, and was transferred to volumetric soil moisture

$$
\theta=\rho_{d} \cdot w
$$

where $\theta$ is volumetric water content, $\rho_{d}$ is bulk density, $w$ is gravimetric water content. Bulk density $\rho_{d}$ has a value of $1,35 \mathrm{~g} \cdot \mathrm{cm}^{-3}$ in Malanta locality. 


\section{Modeled soil moisture}

The Global Model is a numerical model for water movement in the soil root zones (Research Report Institute of Hydrology, Slovak Academy of Sciences, Bratislava, Slovak Republic) [9-11]. The basic saturated and unsaturated water flow is simulated by using Richard's equation

$$
\frac{\partial h_{w}}{\partial t}=\frac{1}{c\left(h_{w}\right)} \frac{\partial}{\partial z}\left[k\left(h_{w}\right)\left(\frac{\partial h_{w}}{\partial z}+1\right)\right]-\frac{S(z, t)}{c\left(h_{w}\right)},
$$

where $h_{w}$ is soil water pressure head $(\mathrm{cm}), k$ is unsaturated hydraulic conductivity $\left(\mathrm{cm} \cdot \mathrm{s}^{-1}\right), S(\mathrm{z}, t)$ is intensity of water uptake by roots $\left(\mathrm{s}^{-1}\right), z$ is vertical co-ordinate $(\mathrm{cm})$, $t$ is time (s), $c\left(h_{w}\right)$ is capacity defined like

$$
c\left(h_{w}\right)=\frac{\partial \theta}{\partial h_{w}},
$$

where $\theta$ is volumetric soil moisture $\left(\mathrm{cm}^{3} \cdot \mathrm{cm}^{-3}\right)$. It can be used for the layers of porous media, composed from five layers with different hydrophysical characteristics.

The boundary condition on the soil surface is given by the mean intensity of precipitation reduced by interception of canopy. Part of precipitation or irrigation amount which is not infiltrated into the soil is then accumulated on the soil surface. In the days without any precipitation the intensity of water transport from the surface to the atmosphere equals evaporation intensity. Transpiration intensity equals intensities of water uptake by roots. In view of relatively small interception quantities and high intensities of evaporation of intercepted water a quantitative influence of evaporation by interception is not assumed in the Model.

The lower boundary condition is defined by the mean values of soil water potential or by the vertical of water flow at a corresponding depth under the soil surface. The zero value of the soil potential assumed at the groundwater flow is not the subject of simulation in the Global Model.

\section{Input files}

The Global Model requires the following input files:

- Van Genuchten index $(\alpha, N)$ to calculate the retention curve;

- input file about soil properties;

- meteorological conditions [12, 13];

- fenological, lower boundary condition input files.

The top boundary condition was to map meteorological and fenological factors and bottom boundary condition was to limit the groundwater level. Soil parameters were obtained from pressure heads and other hydrological experiments.
It is important to have exact inputs for the Model, for example, the depth of soil profile, Genuchten's coefficients for calculating a retention curve, saturation hydraulic conductivity, residual water content, drying branches of the retention curve, and initial boundary conditions.

Measured and simulated results were analysed and evaluated by two methods. The first one was correlation of these results, and the second one was percentage representation according to $15 \%$ difference at least $80 \%$ of equality [14].

\section{Results and Discussion}

The analysed season is limited by the growing season of sugar beet (24/5-27/9), which was grown in the locality of Koliňany. There was no crop in Malanta locality, what is the standard for agro-meteorological station.

\section{Locality of Kolíñany (sugar beet crop): results}

We can state that by correlating simulated and measured courses of soil moisture (Figs 1-3) the highest percentage representation of identical measured and simulated values within difference of $15 \%$ was in 2004 with $75 \%$, in 2002 - with $68 \%$ and in 2003 it was $33 \%$ (Table 1).

In the second step the simulated and measured values of soil moisture were tested by using correlation analysis.

The correlation coefficient between simulated and measured values was high in 2004 (with $r=0,90$ ), and then it was with $r=0,74$ in 2003 , and with $r=0,62$ in 2002.

The year 2004 was the most successful from the point of view of correlation between simulated and measured courses of soil moisture. Simulated values referred to the previous three years of crop rotation with a result which was very close to the measured values.

\section{Locality of Malanta (without plants): results}

Satisfactory correlation was not reached from the point of view of percentage representation of identical measured and simulated values within difference of $15 \%$ in the locality of Malanta (Figs 4-6). It was only $6 \%$ in 2004, $38 \%$ in 2003 and only $16 \%$ in 2002. Correlation coefficient between simulated and measured values of soil moisture reached the value of closeness $r=0,87$ in 2004, $r=0,66$ in 2003, and $r=0,36$ in 2002 (Table 5).

The final result is that a satisfactory correlation was reached between simulated and measured values of soil moisture time series (using the Global Model) only in a locality with crop (sugar beet - Kolíňany). The results obtained by simulation in comparison with measured values were underestimated approximately from 15 to $27 \%$ in a locality without crop (Malanta) (Table 5).

Table 5. Correlation coefficient between simulated and measured values and percentage representation of identical measured and simulated values within difference of $15 \%$

\begin{tabular}{c|c|c|c|c|c|c}
\hline \multirow{2}{*}{ Locality } & \multicolumn{3}{|c|}{ Correlation coefficient } & \multicolumn{3}{c}{ Conjunction to $15 \%$ differences } \\
\cline { 2 - 7 } & 2002 & 2003 & 2004 & 2002 & 2003 & 2004 \\
\hline Kolín̆any & 0,62 & 0,74 & 0,90 & $68 \%$ & $33 \%$ & $75 \%$ \\
\hline Malanta & 0,36 & 0,66 & 0,87 & $16 \%$ & $38 \%$ & $6 \%$ \\
\hline
\end{tabular}




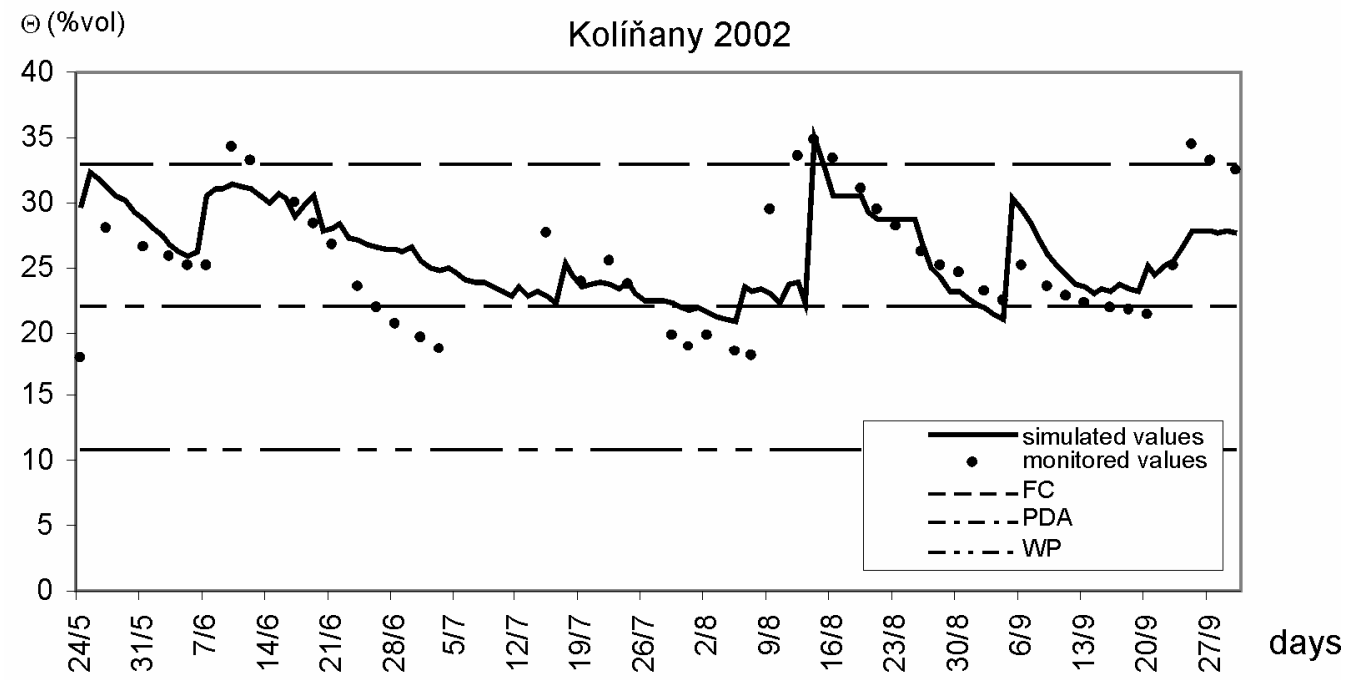

Fig 1. Measured and simulated values of volumetric soil water content in study area of Kolíňany in 2002

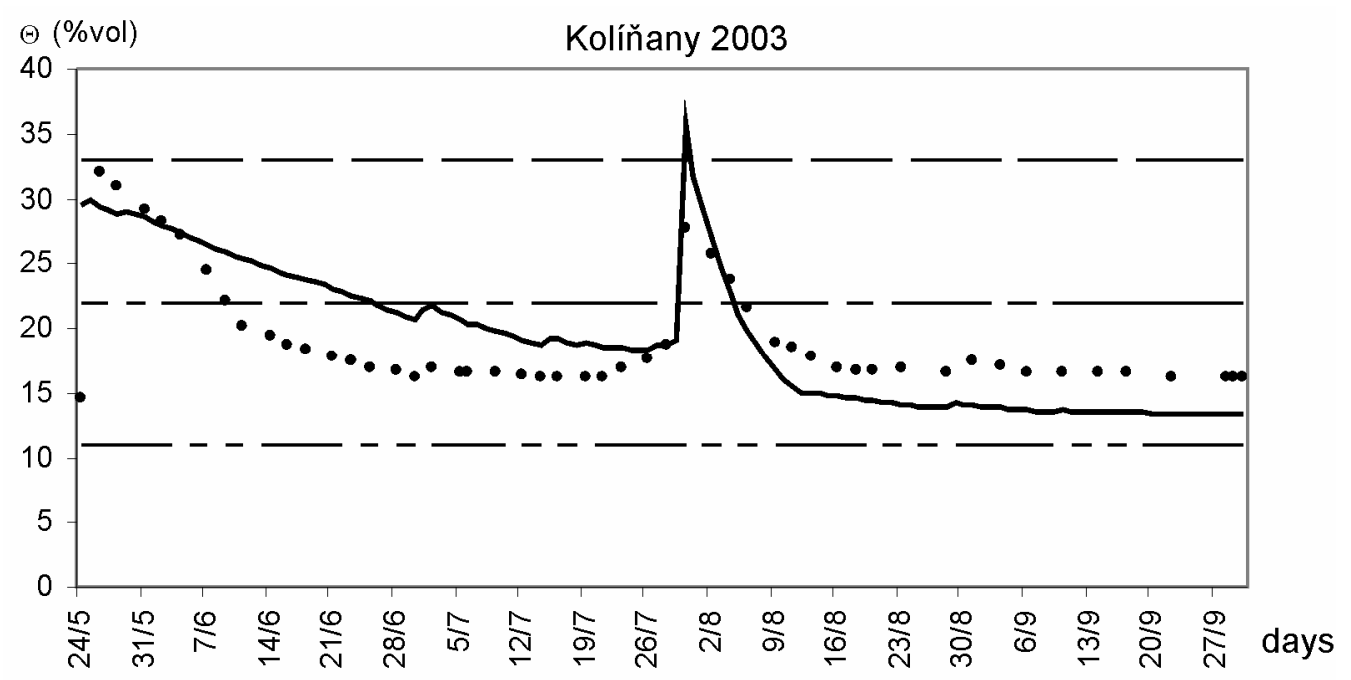

Fig 2. Measured and simulated values of volumetric soil water content in study area of Kolíñany in 2003

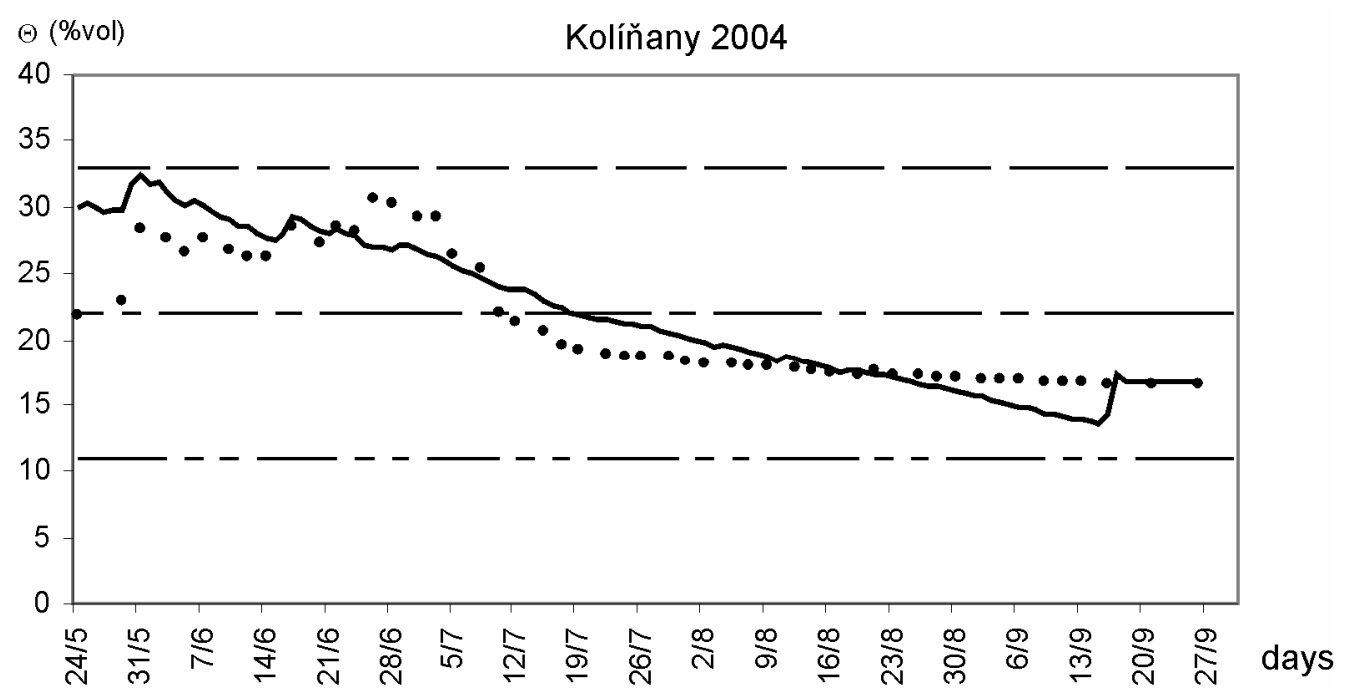

Fig 3. Measured and simulated values of volumetric soil water content in study area of Kolíñany in 2004 


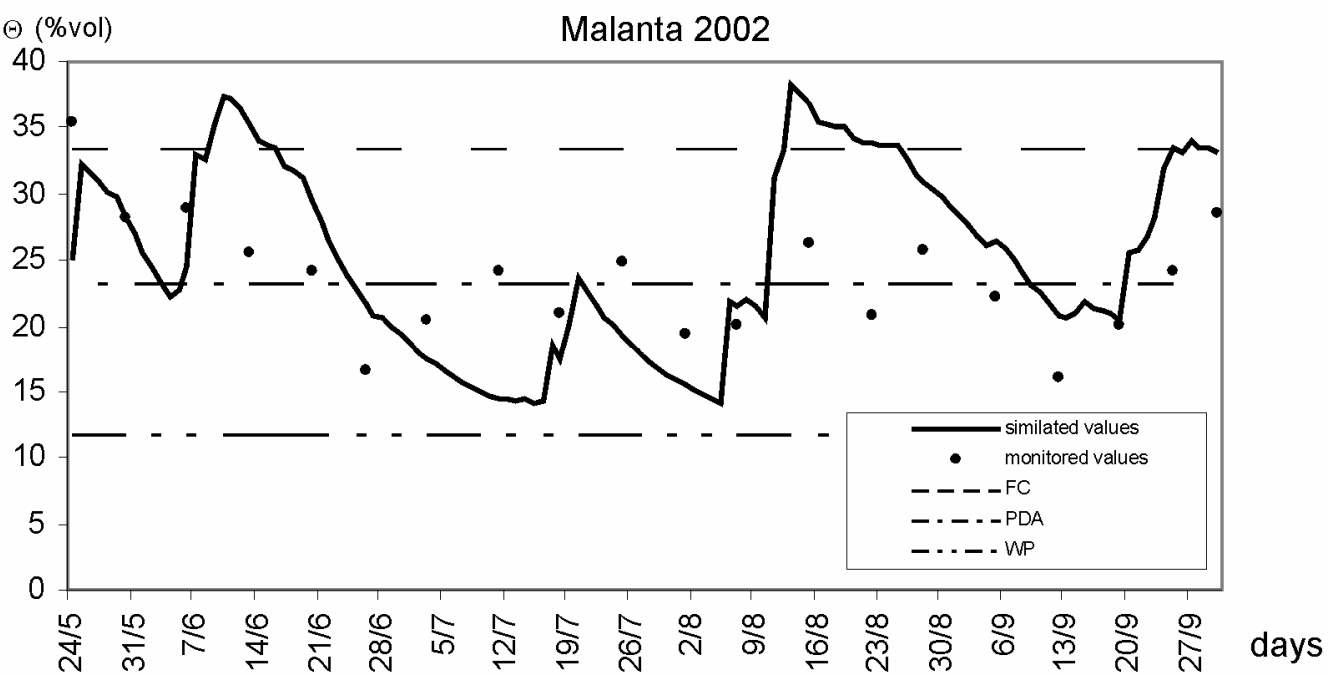

Fig 4. Measured and simulated values of volumetric soil water content in study area of Malanta in 2002

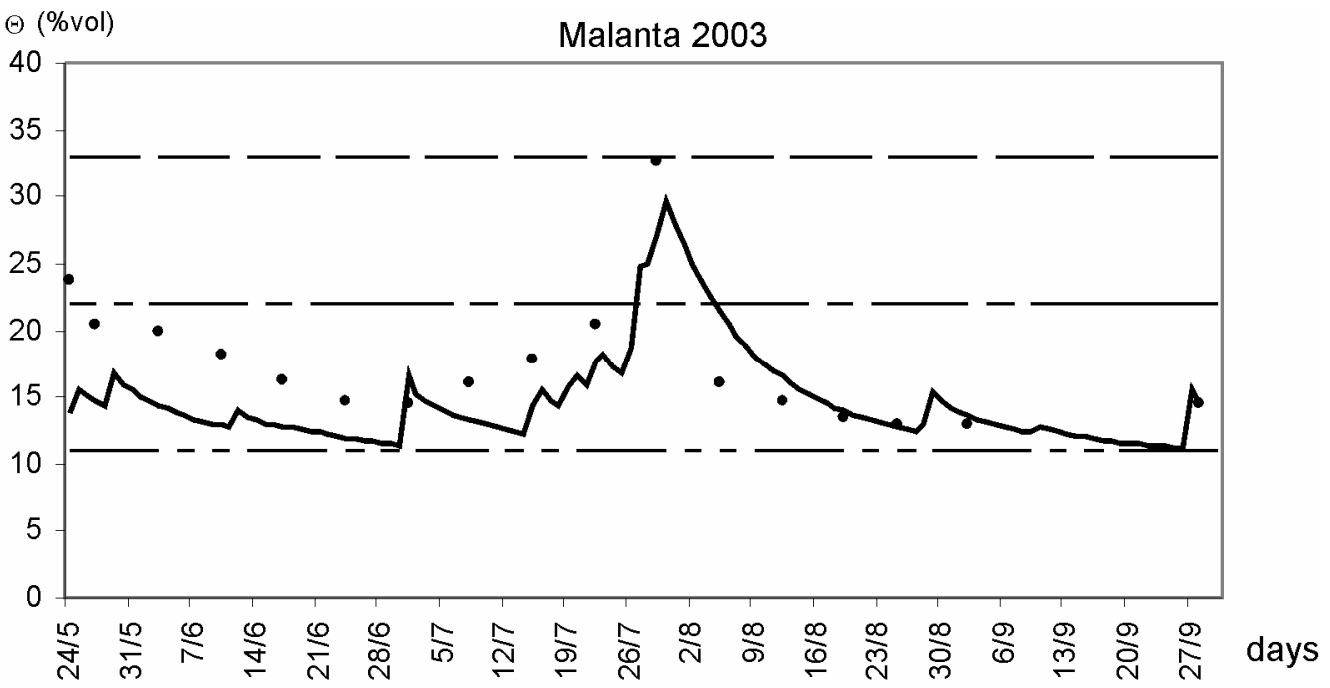

Fig 5. Measured and simulated values of volumetric soil water content in study area of Malanta in 2003

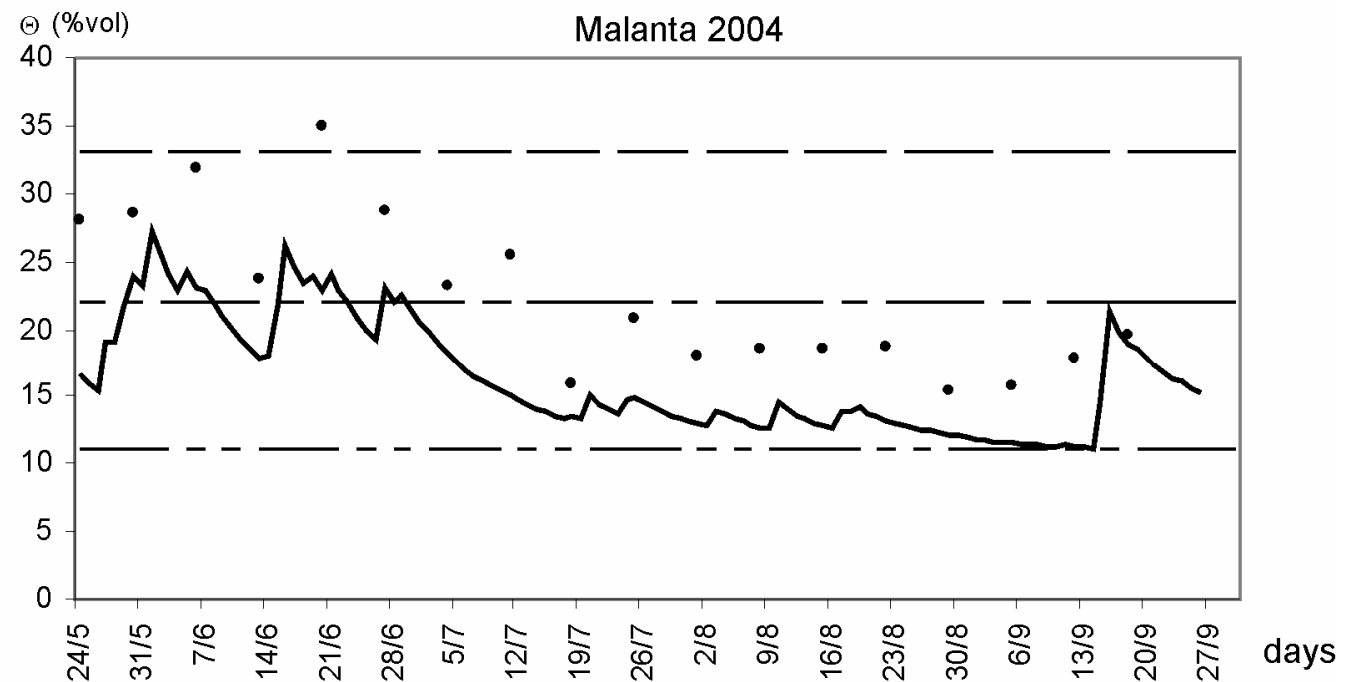

Fig 6. Measured and simulated values of volumetric soil water content in study area of Malanta in 2004 


\section{Conclusions}

Models, science and practical exploitation are included in the investigation. Water content indicates how much water is present in the soil. It can be used to estimate the amount of stored water in a profile or it can be used to estimate how much irrigation is required to reach a desired amount of water. Soil water regime forebodes its development. It is possible to determine resources and pollution of groundwater. We can prognosticate the amount of potential plant production.

Parts of the hydrological balance equation can be formulated by numerical models. It means evapotranspiration, infiltration and so on. The models have provided a systematic study of changes in the soil water regime at a different crop rotation.

It is necessary to have exact inputs to reach very close interaction. The Global Model can be used for further scientific aims instead of too expensive observations.

\section{Acknowledgements}

This investigation was supported by Science and Technology Assistance Agency under the Contract No APVT 51-019804, by the Science Granting Agency under the Contract No VEGA 2/6018/26 and by the Granting Agency SAU under the Contract No 712/04140.

\section{References}

1. KLOPČEK, A.; BÁREK, V. Hydromechanika, 2. Nezmenené vyd. Nitra: SPU, 1999. 226 s. ISBN 80-7137-643-4

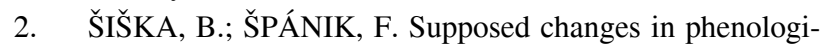
cal relation of Winter wheat and Spring barley as a consequence of climate change impacts in Danubian lowland up to 2075. Meteorological Journal, No 3, Bratislava, 1999, s. 35-40. ISSN 1335-339X

3. ŠIŠKA, B.; ŠPÁNIK, F. TOMLAIN, J. Changes of phenological characteristics of long vegetative period as inf- luenced by climate change impacts. Meteorological Journal, 1, 2000, Bratislava, s. 19-26.

4. ŠIŠKA, B. Supposed impacts of increased concentration of $\mathrm{CO}_{2}$ on yields of spring barley in the region of Danubian lowland up to 2075. Acta Horticulturae et Regiotecturae, 1997, 2, s. 107-120. ISBN 80-7137-435-0

5. KOVÁČ, K.; ČIMO, J.; ŠPÁNIK, F.; MACÁK, M. Agroklimatické podmienky tvorby úrod jačmeňa siateho jarného. In Bioklimatologie současnosti a budoucnosti: $X V$. Československá bioklimatologická konference, 2005, s. 86-88. ISBN 80-86690-31-08

6. ANTAL, J. Agrohydrológia. VŠP. Nitra, 1996.

7. CHLPÍK, J.; POSPÍŠIL, R. Plošná charakteristika mechanických a chemických vlastností pôdy na výskumnej báze Slovenskej pol'nohospodárskej univerzity v Nitre, lokalita Kolíňany. In Acta fytotechnica at zootechnica, 2004, roč. 7, č. 1, s. 6-10. ISSN 1335-258-X

8. HANÁČKOVÁ, E. Zmeny anorganického dusíka v pôde a ich vplyv na úrodu a kvalitu repy cukrovej. In $V$. celoslovenská vedecká repárska konferencia. Nitra: SPU, 2003, s. 176-180. ISBN 80-8069-280-7

9. ŠTEKAUEROVÁ, V.; MAJERČÁK, J.; ŠÚTOR, J. Kvantifikácia zložiek vodnej bilancie v nenasýtenej oblasti pôdy. In Acta Hydrologica Slovaca, 2001, roč. 2, č. 2, s. $183-190$.

10. MAJERČÁK, J.; NOVÁK, V. GLOBAL - a numerical model for water movement in the soil root. Research Report, Institute of Hydrology, SAV: Bratislava, 1995.

11. MAJERČÁK, J. Matematický simulačný model ako nástroj pre diagnózu a prognózu vodného režimu pôdneho profilu s rastlinným krytom: dizertačná práca. Bratislava, 2002. $111 \mathrm{~s}$.

12. ŠŠSKA, B.; REPA, Š. Klimatická charakteristika roku 2002 v Nitre. SPU: Nitra. 31 s. ISBN 80-8069-219-X

13. ŠIŠKA, B.; REPA, Š. Klimatická charakteristika roku 2003 v Nitre. SPU: Nitra. 22 s. ISBN 80-8069-384-6

14. ŽALUD, Z. Možnosti využitia modelu CERES-WHEAT. In Atmosféra 21. Storočia, organizmy a ekosystémy. Zborník z medzinárodnej vedeckej konfer. TU, Zvolen, 1999, s. 226-230.

\section{DIRVOŽEMIO DRE்GMĖS JUDE்JIMO MODELIAVIMAS SLOVAKIJOS KLIMATO SĄLYGOMIS TAIKANT HAPLLICC LUVISOLS (HMm) IR ALBI HAPLLIC LUVISOLS (HMI) MODELIUS}

\section{Tóthová, D. Igaz, J. Antal}

S antrauka

Tyrimo tikslas yra dviejų vietovių (Kolínany ir Malanta) modeliavimas taikant globalujji modeli, remiantis Slovakijos žemès ūkio universiteto (SŽŪU) tyrimų baze. Dirvožemio drėgmé buvo išmatuota ir palyginta su gautais taikant globaluji modelị Kolíňany vietovės modeliavimo duomenimis. Dirvožemio drègmė matuota taikant gravimetrinị metodą Malanta vietoveje. Cukriniai runkeliai augo Kolín̆any, o Malanta vietoveje nebuvo jokių augalų. Eksperimentas truko trejus metus (2002-2004), todèl išmatuoti ir sumodeliuoti vandens sudèties šaltiniai buvo testuojami koreliacine analize Excel programa. Rezultatų tarp sumodeliuotų ir išmatuotų verčių skirtumai turètų siekti 15 \% skirtumą mažiausiai 80 \% lygybei. Koreliacija tarp išmatuotų ir sumodeliuotų verčių buvo reikšminga Kolín̆any vietovei (santykiu 0,62-0,90). Lygybė tarp išmatuotų ir sumodeliuotų verčių buvo nuo $33 \%$ iki $75 \%$ pagal $15 \%$ skirtumą.

Reikšminiai žodžiai: dirvožemis, vandens sudėtis, drègmė, matematinis globalusis modelis, koreliacija, gravimetrinis metodas. 
МОДЕЛИРОВАНИЕ ПЕРЕМЕЩЕНИЯ ГРУНТОВОЙ ВЛАГИ В КЛИМАТИЧЕСКИХ УСЛОВИЯХ СЛОВАКИИ С ПОМОЩЬЮ МОДЕЛЕЙ НАPLLICC LUVISOLS (HMm) ir ALBI HAPLLIC LUVISOLS (HMI)

\section{И. Тотгова, Д. Игаз, Я. Антал}

Резюме

Целью исследования было моделирование перемещения грунтовой влаги двух местностей (Колинани и Маланта) с использованием Глобальной модели на базе исследований Словацкого университета сельского хозяйства. Влажность грунта была измерена и сравнена с полученными с помощью Глобальной модели данными для местности Колинани. Измерение влажности грунта по гравиметрическому методу осуществлялось для местности Маланта. Во время эксперимента в Колинани выращивалась сахарная свекла, в то время как в Маланте растений не было. Эксперимент длился три года (2002-2004), поэтому измеренные и смоделированные источники состава воды тестировались с помощью корреляционного анализа по программе Excel. Разница результатов измеренных и смоделированных величин составила $15 \%$ для 80 \% равенств. Корреляция между измеренными и смоделированными величинами наиболее значительной была для местности Колинани $(0,62-0,90)$. Равенство измеренных и смоделированных величин составило от $33 \%$ до $75 \%$ при $15 \%$-ой разнице.

Ключевые слова: грунт, состав воды, влажность, математическая Глобальная модель, корреляция, гравиметрический метод.

Iveta TÓTHOVÁ. PhD-student, Dept of Biometeorology and Hydrology, Slovak Agricultural University in Nitra (SAU), Hospodárska 7, 94976 Nitra, Slovak Republic.

Publications: author (with co-authors) of 5 scientific publications. Research interests: problems of mathematical modelling of soil water regime and transport of nutriment to the groundwater level.

Dušan IGAZ. PhD, assistant, Dept of Biometeorology and Hydrology, Slovak Agricultural University in Nitra (SAU), Hospodárska 7, 94976 Nitra, Slovak Republic.

Publications: author (with co-authors) of 30 scientific publications. Research interests: agrohydrology, soil water regime, influence of anaerobically modified slurry after biogas production on hydrophysical soil properties.

Jaroslav ANTAL. Prof, DrSc Head of Dept of Biometeorology and Hydrology, Slovak Agricultural University in Nitra (SAU), Hospodárska 7, 94976 Nitra, Slovak Republic.

Publications: author (with co-authors) of more than 100 scientific publications. Research interests: problems of soil water regime and transport of nutriment to the groundwater level, hydrology, agrohydrology, water erosion, soil conservation. 